\title{
Philosophy
}

\section{The Journal of the Royal Institute of Philosophy}

\author{
edited by \\ RENFORD BAMBROUGH
}

\section{Volume 50 1975}

CAMBRIDGE UNIVERSITY PRESS CAMBRIDGE - LONDON - NEW YORK 
Published by the Syndics of the Cambridge University Press The P.H. Building, Trumpington Street, Cambridge CB2 IRP Bentley House, P.O. Box 92, 200 Euston Road, London, NWI $2 \mathrm{DB}$ 32 East 57th Street, New York, N.Y. 10022

(C) The Royal Institute of Philosophy 1975

Printed in Great Britain by Adlard $\mathbb{E}$ Son Ltd, Bartholomew Press, Dorking 


\section{CONTENTS}

\section{ARTICLES}

Armstrong, D. M. Towards a Theory of Properties

page 145 BennetT, Jonathan Philosophy and Mr Stoppard BROWN, NORMAN J. A Kind of Necessary Truth

BRYDEN, RICHARD On Taking Liberties with Will

CANFIELD, JOHN V. Wittgenstein and Zen

CARgile, JAmes The Ontological Argument

COADY, C. A. J. Collingwood and Historical Testimony

DAVIES, C. A. Morality and Ignorance of Fact

DEVINE, PHILIP E. Does St Anselm Beg the Question?

\section{DISCUSSION}

ATTFIELD, ROBIN Against Non-Comparabilism
BENDITT, THEODORE A Problem for Theodicists
CHOPRA, Y. N. Worshipping the Right God
COADY, MARGARET M. Considering Equality
FOOT, PHILIPPA A Reply to Professor Frankena
GIBBS, BENJAMIN Can God Do Evil?
HARRIS, JOHN The Survival Lottery
HINTON, R. T. Is the Existence of Pain a Scientific Hypothesis?
HOFFMAN, ROBERT Scientific Research and Moral Rectitude
ROLENDA, KONSTANTIN Moral Conflicts and Universalizability
MEYNELL, HUGO On Geese and R. K. Jones
MILLER, ARTHUR R. The Locutionary-Illocutionary Distinction
MURE, G. R. G. Cause and Because in Aristotle
PALMER, ANTHONY Understanding and Experience: Recent Work in the
Philosophy of Mind
PARKINSON, G. H. R. From Descartes to Collingwood: Recent Work on
the History of Philosophy




\section{REVIEWS}

BAMBRoUgh, RENFord (ed.) Wisdom: Twelve Essays (Peter Winch)

Chatterjee, margaret (ed.) Contemporary Indian Philosophy, Series

Two (T. L. S. Sprigge)

cunningham, Frank Objectivity in Social Science (David Papineau) 364

harrison, Ross On What There Must Be (R. G. Swinburne)

HOSTlER, JOHN Leibniz's Moral Philosophy (R. S. Woolhouse)

HU.TER, J. F. M. Essays after Wittgenstein (R. W. Newell)

KENNY, ANTHONY Wittgenstein (Stuart Brown)

Körner, stephan (ed.) Practical Reason (Barrie Paskins)

LEHRER, KEITH Knowledge (J. D. Kenyon)

Lessnoff, michael. The Structure of Social Science: $A$ Philosophical

Introduction (David Papineau)

MACкiE, J. 2. The Cement of the Universe: A Study of Causation

(Martin Hollis)

MELLOR, D. H. A Matter of Chance (John Watling)

PASSMORE, JOHN Man's Responsibility for Nature (Mary Midgley)

SCRUTON, Roger Art and Imagination (W. Charlton)

Strawson, P. F. Subject and Predicate in Logic and Grammar (David

Holdcroft)

Thorpe, W. H. Animal Nature and Human Nature (Hugo Meynell)

UNGER, PETER Ignorance: A Case for Scepticism (C. H. Whiteley)

\section{NOTES AND NOTICES}

Editorial: Fifty Years of Philosophy

Life and Death Sciences

Booknotes

Books Received 